\title{
Prey Selectivity and Diet of Striped Bass in Western Albemarle Sound, North Carolina
}

\author{
Paul J. Rudershausen,* Jack E. Tuomikoski, and Jeffrey A. Buckel \\ Center for Marine Sciences and Technology, \\ Department of Zoology, North Carolina State University, \\ 303 College Circle, Morehead City, North Carolina 28557, USA
}

\section{Joseph E. Hightower}

\author{
U.S. Geological Survey, North Carolina Cooperative Fish and Wildlife Research Unit, \\ Department of Zoology, North Carolina State University, \\ Campus Box 7617, Raleigh, North Carolina 27695-7617, USA
}

\begin{abstract}
We collected 1,399 striped bass Morone saxatilis from western Albemarle Sound, North Carolina, during May through October of 2002 and 2003 to characterize diet, prey type selectivity, and prey size selectivity. Herrings Alosa spp., Atlantic menhaden Brevoortia tyrannus, bay anchovy Anchoa mitchilli, silversides Menidia spp., and yellow perch Perca flavescens dominated the diets of age- 1 striped bass, while Atlantic menhaden dominated the diets of older striped bass. Selectivity was calculated for three categories of striped bass (ages 1, 2, and 3+ [3-7]) based on fish prey collections from a $61-\mathrm{m}$ beach seine and a $76-\mathrm{m}$ purse seine. Striped bass of all ages primarily consumed fish prey regardless of the month or year. Each age category of striped bass selected for one or more species of prey from the suborder Clupeoidei. Age-1 striped bass selectivity of Alosa spp. generally increased with the progression of each sampling season, whereas selectivity for Atlantic menhaden, Menidia spp., and yellow perch decreased over time within each season. Striped bass of all ages displayed strong selection for Atlantic menhaden and strong selection against spiny-rayed fish prey. Striped bass displayed selection for specific prey, although the mechanisms responsible for selection appear to vary through time and may differ for different prey types. Striped bass either displayed neutral size selectivity or selected for relatively small prey. The mean and maximum sizes of fish prey increased with increases in striped bass size, but the minimum prey size changed little. Our results of seasonal and age-specific changes in selectivity will be valuable for modeling the impact of striped bass predation on resource prey species.
\end{abstract}

The predatory effects of piscivores are important in structuring prey fish communities (Forney 1974). Because piscivores generally exhibit selection for smaller prey (Juanes 1994; Juanes and Conover 1994), prey species recruitment may be limited by predation on early life stages, when prey vulnerability is high (Nielsen 1980; Tonn et al. 1992). Research on predator diets is important for determining trophic linkages and thus for successfully managing populations of predator and prey fishes (Livingston 1985). Additionally, multispecies fishery management models require detailed predator dietary data to accurately account for the population-level effects of predation (Livingston 1985).

The striped bass Morone saxatilis is a common predator in U.S. East Coast estuaries. After declining markedly in the 1970s and 1980s, the At-

\footnotetext{
* Corresponding author: pjruders@unity.ncsu.edu
}

Received July 4, 2004; accepted February 15, 2005 Published online July 11, 2005 lantic coast striped bass population rebounded dramatically in the 1990 s and is now at or near a record high (Hartman and Margraf 2003). Similar to other coastal stocks, the number of age- 4 and older striped bass in the Albemarle Sound-Roanoke River stock has increased eightfold since the early 1990s (Carmichael 2003). Current populations of Atlantic coast striped bass may have the capacity to reduce populations of fish prey (Hartman 2003) and thus impact recruitment of estuarine fishes.

The diet of striped bass in the Albemarle Sound estuary includes commercially and ecologically important species, such as the blueback herring Alosa aestivalis, alewife A. pseudoharengus, American shad A. sapidissima, and Atlantic menhaden Brevoortia tyrannus (Manooch 1973), whose juveniles use the estuary as a nursery. In contrast to the recent resurgence of striped bass numbers, recruitment failure coupled with high exploitation has resulted in dramatic population declines in blueback herring, alewives, and American 
shad in Albemarle Sound (Carmichael 1999). The specific causes of herring Alosa spp. recruitment failure in western Albemarle Sound are unknown, but one potential factor may be the relatively large population of striped bass. Information about the predatory impact of striped bass on age0 fish of Alosa spp. is needed in order to develop effective rebuilding strategies for these depleted stocks.

Striped bass have been described as opportunistics, generalists, and selective feeders throughout their range in the wild (Merriman 1941; Raney 1952; Manooch 1973; Boynton et al. 1981; Gardiner and Hoff 1982; Matthews et al. 1988; Cooper et al. 1998), and clupeid prey dominate the diets of Atlantic coast populations (Walter et al. 2003). Selection may be active (i.e., reflecting preferences for a particular prey) or passive (i.e., reflecting differences in the relative vulnerability of prey types). Despite the widespread distribution of striped bass in Atlantic coastal systems, the potential for this species to impact prey populations, and the research describing striped bass feeding strategies, we know of no previous work that has quantified prey size selectivity or prey type selectivity by juvenile or adult striped bass in the wild. Nelson et al. (2003), for example, found that the average size of fish prey consumed did not increase in proportion to striped bass size, yet no data was presented on the relative availability of prey sizes in the environment. Recent studies (e.g., Nelson et al. 2003) have called for the need to quantify wild-caught striped bass diet selectivity by collecting environmental data on the relative abundances and sizes of available prey. Additionally, size-specific diet data for striped bass in North Carolina is largely lacking (Walter et al. 2003). Predictive multispecies models benefit from this type of diet and selectivity information.

This study quantified the diet and overall selectivity of striped bass in Albemarle Sound. We hypothesized that striped bass would randomly (nonselectively) feed with respect to both prey type and prey size in the study area. Because this study was part of a larger effort to examine the predatory impact of striped bass on Alosa spp., we focused on the diets of striped bass in the summer and early fall, which constitute the summer nursery period for age-0 Alosa spp. Although we analyzed the diets of age-1+ striped bass, we focused primarily on age-1 fish for two reasons. First, these younger predators have a potentially larger impact than older striped bass due to the combination of their relatively high abundances and high weight- specific consumption rates (Cyterski et al. 2002). Second, age-1 striped bass experience lower thermal stress than older striped bass subjected to similar summer temperatures in Albemarle Sound (Haeseker et al. 1996). We expected that striped bass in Albemarle Sound would feed in littoral and offshore environments, and therefore we collected predators and prey from both areas.

\section{Study Area}

The Chowan and Roanoke rivers create an oligohaline environment in western Albemarle Sound (Bowden and Hobbie 1977; Giese et al. 1985). This area receives salt water from the Atlantic Ocean indirectly through Oregon Inlet. Salinity in this part of the sound is inversely related to river flow (Bowden and Hobbie 1977) and is generally less than 5\%o (Copeland et al. 1984). Maximum depth is roughly $5.5 \mathrm{~m}$ (Heath 1983). High winds tend to remove vertical stratification in temperature, dissolved oxygen, and salinity (Bowden and Hobbie 1977; Giese et al. 1985; Garrett 1993). Fixed sampling sites were located from $8 \mathrm{~km}$ north of the Highway 17 bridge downstream to the Highway 32 bridge (Figure 1). Eleven years of sampling by the North Carolina Division of Marine Fisheries (NCDMF) documented a relatively high abundance of age-0 Alosa spp. during the summer and early fall in this section of the sound (Sara Winslow, NCDMF, unpublished). The NCDMF alosine survey and the 2001 gut data (see below) indicated that the highest overlap between age- 1 striped bass and age- 0 alosines in any given year would probably occur in western Albemarle Sound.

\section{Methods}

Potential prey fishes and striped bass were sampled during May through October of 2002 and 2003; beach seine and purse seine collections were made approximately biweekly. The 61-m $\times 3-\mathrm{m}$ beach seine $(6.4-\mathrm{mm}$ bar-mesh wings and $4.8-\mathrm{mm}$ delta-mesh bag) was set by boat at 18 fixed stations during daylight hours. The $76-\mathrm{m} \times 6$ - $\mathrm{m}$ purse seine (7.6-mm bar mesh) was set and retrieved at night by a single boat at 12 fixed sampling stations that were selected based on sufficient depth and absence of obstructions. The purse seine was deployed in a counterclockwise circle from the anchored end of the net. Potential prey fishes were enumerated from each collection, and a subsample of each prey species (up to 30 individuals) was measured. All Alosa spp. prey were preserved (95\% ethanol) for later identification.

Additional striped bass were collected by hook 


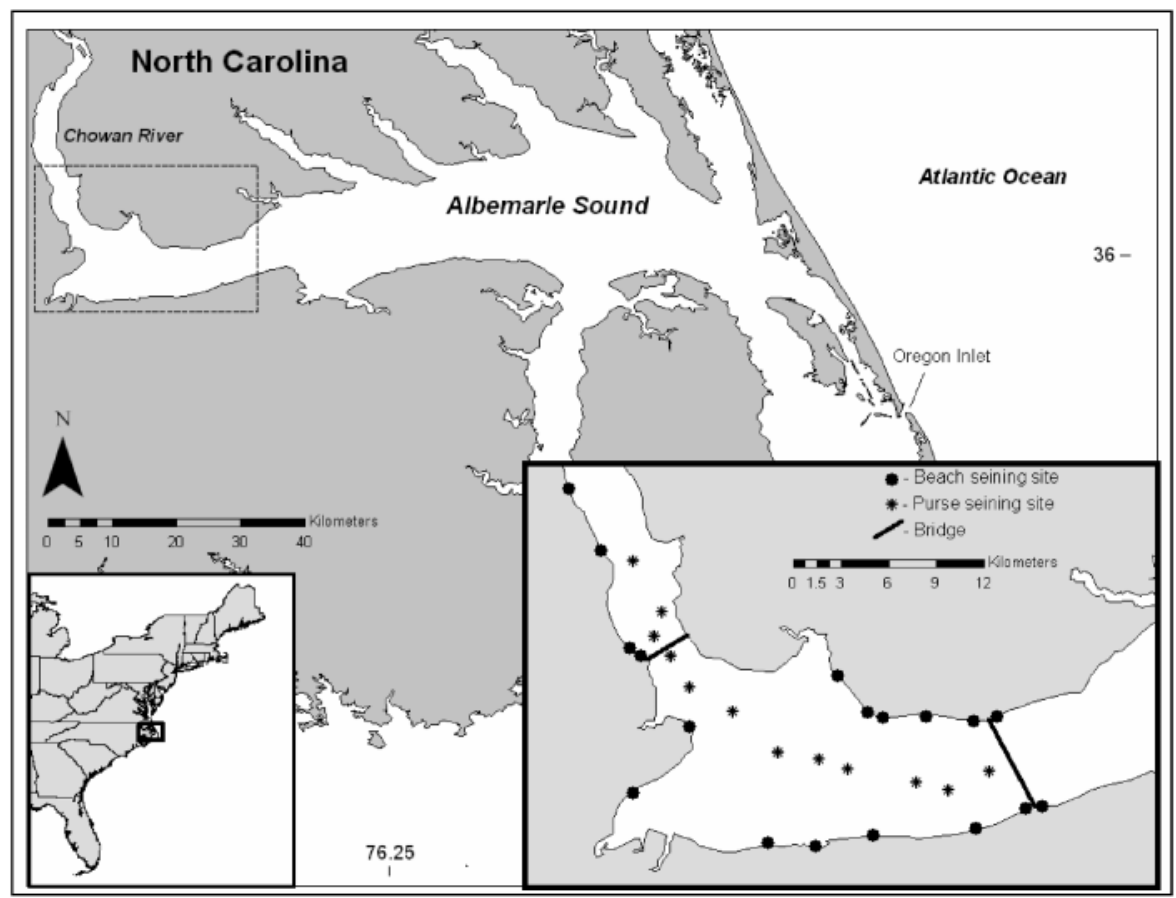

FIGURE 1.-Map showing the beach and purse seine sampling sites used to sample striped bass and their prey in western Albemarle Sound, North Carolina, 2002-2003.

and line, electrofishing, and gill netting. Experimental gill nets (stretched mesh sizes of 13, 25, $38,51,64$, and $76 \mathrm{~mm}$ ) were soaked for $1 \mathrm{~h}$ or less to minimize regurgitation or digestion of stomach contents (Sutton et al. 2004). Much of this effort occurred near bridges, where striped bass tended to aggregate. Age- 1 striped bass were immediately preserved whole in $10 \%$ buffered formalin and were weighed $(\mathrm{g})$ and measured (fork length [FL] and total length [TL], $\mathrm{mm}$ ) in the laboratory. For age- $2+$ striped bass, we were concerned with sufficient preservation of whole specimens, so stomachs were excised and preserved in formalin after weights and measurements (as above) were made. Environmental conditions (water temperature $\left[{ }^{\circ} \mathrm{C}\right]$, salinity $[\% o]$, and dissolved oxygen $[\mathrm{mg} / \mathrm{L}]$ ) were measured in conjunction with each collection of fishes.

Striped bass ages were determined by counting annuli from whole sagittae taken from a subsample $(n=181)$ of specimens that encompassed the complete size range collected and by examining modal distributions from length-frequency histograms. Ages of otoliths were in close agreement with the distributions of modes from striped bass lengthfrequency histograms. Hence, we divided striped bass into three age categories $(1,2$, and $3+[3-7]$ years) for all diet analyses.

Striped bass stomach contents were identified to the lowest possible taxon, enumerated, blotted dry, weighed $(0.001 \mathrm{~g})$, and, when possible, measured (FL; $0.1 \mathrm{~mm}$ ). Identification of well-digested fish prey was aided by inspection of scales and jaw morphology. In the case of Alosa spp., the color of the peritoneum and the shape of the mandible permitted identification of some well-digested individuals. Identification of Atlantic menhaden in the stomachs of striped bass was often possible by the presence of their distinctively shaped gizzard.

Striped bass diets were quantified by percent frequency of occurrence and percent weight. Percent weight was calculated based only on organic, identifiable food items. Mean estimates for percent frequency and weight diet indices were calculated with cluster sampling estimators (see Buckel et al. 1999 for a description of these calculations). These estimates were used because each collection (an individual seine haul) of a specific age-class of striped bass provided us with a group or "cluster" of nonindependent fish. Variance estimates around these means are presented elsewhere (Tuomikoski 
2004). Mean values of percent frequency and percent weight by month and striped bass age-class from cluster estimators were normalized to $100 \%$ per month to allow presentation in graphical format.

Piscivorous fishes may consume fish prey in a net in which both are collected, a phenomenon known as net feeding (Buckel et al. 1999). Because net feeding may bias stomach content analyses, we visually estimated the relative state of digestion of the stomach contents of striped bass predators. All prey showed signs of digestion, so there was no evidence of net feeding. Furthermore, the majority of striped bass $(69 \%)$ were caught by electrofishing, gillnetting, or hook and line.

Prey type selectivity by striped bass was determined by comparing the proportional contribution of an individual fish species in striped bass diets with the proportional abundance of that prey species in the environment. This proportional abundance of prey in inshore and offshore environments was separately measured by beach seine and purse seine collections. Prey taxa used for selectivity calculations were determined by selecting the dominant prey for each year and method of collection. Manooch (1973) found that striped bass consumed prey fishes that were up to $62 \%$ of predator body length. Based on this work, other published striped bass feeding studies, and inspection of stomach items, we included in the selectivity analysis those potential prey specimens whose TL was less than $70 \%$ of the monthly average TL for a given age-class of striped bass.

We used Chesson's (1978) index to compute prey type selectivity. Chesson's index is computed as

$$
\alpha_{i}=\frac{r_{i} / p_{i}}{\sum r_{j} / p_{j}}, \quad i=1, \ldots, m
$$

where $\alpha_{i}$ is the selectivity for prey type $i$ for a group of striped bass from a given predator collection; $r_{i}$ is the relative abundance of prey type $i$ for the group of striped bass stomachs in a given collection; $p_{i}$ is the relative abundance of prey type $i$ in the environment, as calculated from the seine catches (purse or beach) made within $10 \mathrm{~d}$ of the striped bass collection date; and $m$ is the number of prey types available $(m=8$ for 2002 beach seining, 4 for 2002 purse seining, 7 for 2003 beach seining, and 4 for 2003 purse seining). Based on the gradual changes in diet and prey abundance that we observed, an interval of $10 \mathrm{~d}$ was considered appropriate. Values of $\alpha_{i}$ were calculated for those seine collections in which at least two striped bass of a given age-class were captured. For each gear type, a value of $p_{i}$ was calculated for the full suite of biweekly collections (collected over $2 \mathrm{~d}$ ). We did not purse seine in May of either year; purse seine selectivity values for age-1 striped bass in May were calculated based on environmental data $\left(p_{i}\right)$ from the first set of June purse seine collections in each year. For calculations of $\alpha_{i}$, random feeding occurs when $\alpha_{i}$ is equal to $1 / \mathrm{m}$. Values of $\alpha_{i}$ greater than $1 / m$ represent selection for prey type $i$, while values of $\alpha_{i}$ less than $1 / m$ represent selection against prey type $i$. Chesson's index assumes that prey abundance is large relative to the amount of food consumed by the predator and that the catchability among different prey is the same for each gear type (Chesson 1978). Further, this approach assumes that different prey types are identifiable at equal time points during digestion.

Chesson's index allows for temporal comparisons among selectivity values even if the relative abundances of prey types in the environment change (Chesson 1983). Further, one can statistically test for differences between a mean selectivity value and the value for random feeding by testing the null hypothesis that Chesson's index $\alpha_{i}$ is equal to $1 / m$ (Chesson 1983). We used this method to analyze monthly and overall prey type selectivity when we had at least two Chesson's values for a given seine type (beach or purse) and a given striped bass age. The $t$-test cannot be computed when all selectivity values for a prey type are zero for a specific gear and time frame (denominator $=$ $0)$.

We analyzed prey size selection by comparing monthly length-frequency distributions of a prey species consumed by an age-class of striped bass with the monthly length-frequency distribution of that prey captured by beach or purse seine. We compared prey sizes from field and gut data with a median test, which examines whether the medians of the populations from which two samples are taken are identical (Zar 1996). The median test was used when at least eight lengths of one prey type were recovered from a monthly sample of one age-class of striped bass, and when at least 20 individuals of that species were collected by beach or purse seining during that month. Many of the Alosa spp. recovered from striped bass stomachs were measurable but were not identifiable to species. Thus, for median tests of size selectivity of Alosa spp., the most abundant Alosa spp. collected monthly from the field was used to compare Alosa spp. length-frequency distributions between field and diet data. 
TABLE 1.- Total fish numbers, numbers with food in their stomachs, mean size (TL; mm), and size range of three age-classes of striped bass captured from Albemarle Sound, North Carolina, in 2002 and 2003.

\begin{tabular}{|c|c|c|c|c|c|c|}
\hline Age & Year & Month & $\begin{array}{l}\text { Number } \\
\text { analyzed }\end{array}$ & $\begin{array}{l}\text { Number } \\
\text { with food }\end{array}$ & $\begin{array}{c}\text { Mean } \\
\text { TL (SD) }\end{array}$ & $\mathrm{TL}$ range \\
\hline \multirow[t]{10}{*}{1} & \multirow[t]{5}{*}{2002} & May & 40 & 33 & $168.5(23.2)$ & $121-240$ \\
\hline & & Jun & 179 & 118 & $172.2(24.0)$ & $130-257$ \\
\hline & & Jul & 121 & 94 & $180.1(26.4)$ & $136-256$ \\
\hline & & Aug & 40 & 28 & $209.3(39.1)$ & $116-274$ \\
\hline & & Sep-Oct & 31 & 23 & $255.2(28.4)$ & $166-294$ \\
\hline & \multirow[t]{5}{*}{2003} & May & 12 & 12 & $173.7(8.9)$ & $162-185$ \\
\hline & & Jun & 49 & 37 & $198.5(29.9)$ & $124-262$ \\
\hline & & Jul & 118 & 77 & $230.5(21.5)$ & $188-280$ \\
\hline & & Aug & 54 & 47 & $242.2(24.3)$ & $198-296$ \\
\hline & & Sep-Oct & 34 & 17 & $261.3(23.4)$ & $221-303$ \\
\hline \multirow[t]{8}{*}{2} & \multirow[t]{4}{*}{2002} & Jun & 19 & 14 & $321.5(31.2)$ & $272-370$ \\
\hline & & Jul & 78 & 53 & $327.3(31.0)$ & $263-390$ \\
\hline & & Aug & 40 & 15 & $331.6(26.7)$ & $280-392$ \\
\hline & & Sep-Oct & 72 & 50 & $351.8(23.1)$ & $300-396$ \\
\hline & \multirow[t]{4}{*}{2003} & Jun & 71 & 20 & $353.4(38.4)$ & $284-430$ \\
\hline & & Jul & 47 & 26 & 354.5 (34.4) & $285-416$ \\
\hline & & Aug & 81 & 58 & $373.2(33.3)$ & $300-445$ \\
\hline & & Sep-Oct & 107 & 71 & $404.4(29.7)$ & $317-470$ \\
\hline \multirow[t]{8}{*}{$3+$} & \multirow[t]{4}{*}{2002} & Jun & 5 & 1 & 469.4 (41.5) & $430-580$ \\
\hline & & Jul & 38 & 22 & 476.7 (35.8) & $405-572$ \\
\hline & & Aug & 65 & 18 & 490.9 (37.7) & $413-576$ \\
\hline & & Sep-Oct & 57 & 30 & $471.2(41.6)$ & $400-613$ \\
\hline & \multirow[t]{4}{*}{2003} & Jun & 5 & 1 & $523.0(37.2)$ & $477-574$ \\
\hline & & Jul & 5 & 1 & $477.6(25.3)$ & $443-505$ \\
\hline & & Aug & 9 & 7 & $495.7(33.0)$ & $461-555$ \\
\hline & & Sep-Oct & 22 & 19 & $478.0(32.0)$ & $445-620$ \\
\hline
\end{tabular}

Prey-predator ratios (PPRs) from gut data were computed for dominant prey types. Fish prey size as a function of predator size was also estimated by quantile regression, which was used to estimate changes in minimum and maximum fish prey size with increasing striped bass size. Regression quantiles are useful in estimating functional changes along boundaries of distributions when the response variable changes at a rate disproportionate with changes in the independent variable (Scharf et al. 1998). We selected the 5th, 50th, and 95th regression quantiles based on published estimates of sample sizes recommended for each quantile (Scharf et al. 1998). The 5th and 95th quantiles were generated to estimate the extremes of prey and predator length data from gut contents and to test the significance of slopes of each quantile. A difference in slopes between these upper and lower quantiles (upper quantile slope significantly different from zero, lower quantile slope not significantly different from zero) indicates a change in the ratio of prey-predator TL with increasing predator size. The PPR and regression analyses of prey versus predator length data included data from a pilot study in 2001 that analyzed diets of 158 age1 striped bass collected from central and western Albemarle Sound. We found from this pilot data that bay anchovy Anchoa mitchilli dominated the diets in terms of percent frequency and percent weight and that blueback herring were of secondary importance.

We tested for switching behavior in age-1 striped bass by correlating selectivity values with respective catch per unit effort of important fish prey. Important fish prey were Alosa spp., bay anchovy, Atlantic menhaden, silversides Menidia spp., and yellow perch Perca flavescens. If switching occurs, selectivity values for a particular prey type will be positively correlated with the absolute abundance of that prey type.

\section{Results}

Water temperature ranged from $20.6^{\circ} \mathrm{C}$ to $30.1^{\circ} \mathrm{C}$ in 2002 and from $19.7^{\circ} \mathrm{C}$ to $29.6^{\circ} \mathrm{C}$ in 2003 . Salinity ranged from $2.0 \%$ to $4.9 \%$ in 2002 and from $0 \%$ to $0.2 \%$ in 2003 . Dissolved oxygen ranged from 2.0 to $9.2 \mathrm{mg} / \mathrm{L}$ in 2002 and from 4.2 to 8.5 $\mathrm{mg} / \mathrm{L}$ in 2003.

We collected and analyzed a total of 411 age1, 209 age- 2 , and 165 age- $3+$ striped bass in 2002 and 267 age- 1,306 age-2, and 41 age- $3+$ striped bass in 2003 (Table 1). Across all ages, 36.8\% of striped bass in 2002 and $35.8 \%$ in 2003 had empty stomachs (Table 1). Fish prey predominated over 


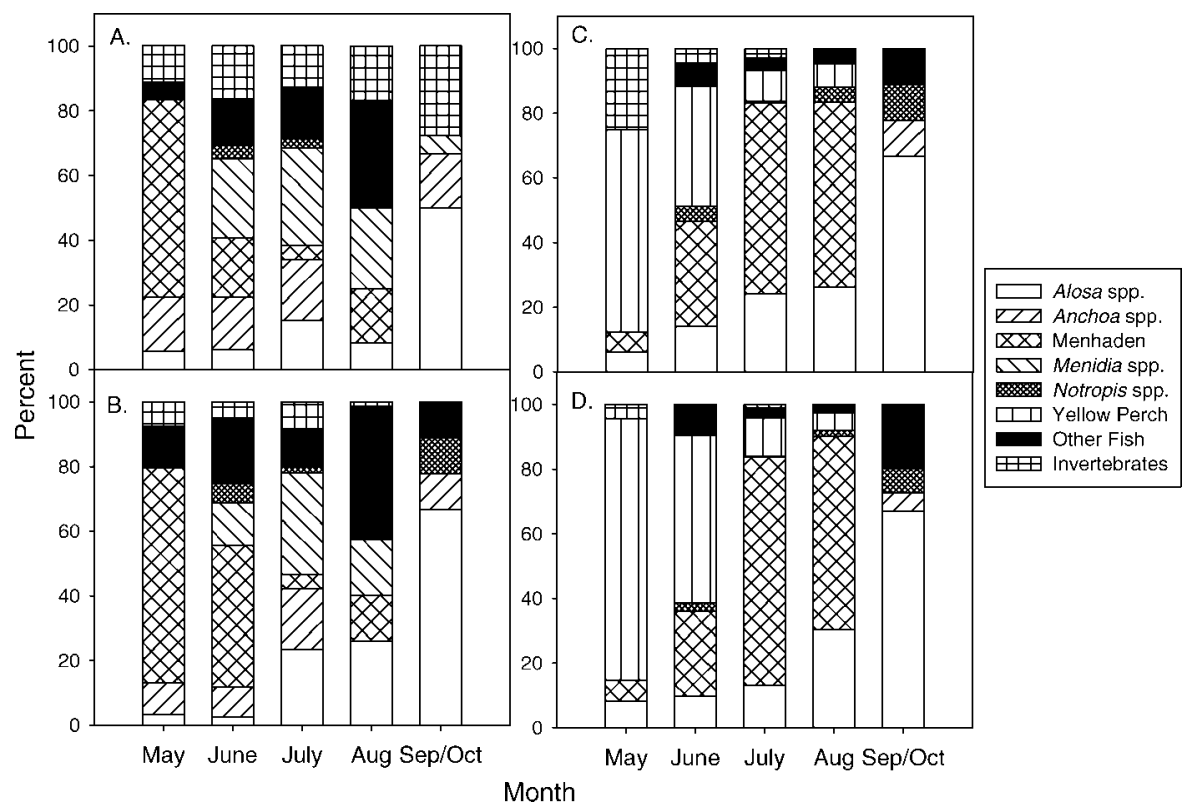

FIGURE 2.- Relative percent frequency by number (upper panels) and weight (lower panels) of major identifiable food groups consumed by age-1 striped bass collected in Albemarle Sound, North Carolina, in (A-B) 2002 and (C-D) 2003. The "other fish" category includes bluefish Pomatomus saltatrix, Atlantic croaker Micropogonias undulatus, Gobiidae, topminnows Fundulus spp., mullets Mugil spp., spotted seatrout Cynoscion nebulosus, striped bass, and white perch Morone americana in 2002 and Atlantic croaker, Fundulus spp., sunfishes Lepomis spp., and white perch in 2003 .

invertebrate prey across all months and predator ages (Figures 2-4). Invertebrates became progressively less important to the diet as striped bass age increased. Prey fishes of the suborder Clupeoidei (families Clupeidae and Engraulidae) dominated gut contents in both 2002 and 2003. Dominant prey taxa in age-1 striped bass diets included the combined Alosa spp. (alewives, American shad, and blueback herring), Atlantic menhaden, anchovies Anchoa spp., and Menidia spp. in 2002; and Alosa spp., Atlantic menhaden, and yellow perch in 2003 (Figure 2). Atlantic menhaden dominated the diets of age- 2 and age-3 + striped bass in 2002 and 2003 (Figures 3, 4). Alosa spp. were not important to the diets of age- 2 and age- $3+$ striped bass in either year.

The advanced state of digestion prevented us from identifying to species many of the alosines found in striped bass stomachs. However, all three major Alosa spp. captured in the field (alewives, American shad, and blueback herring) were identified in the stomachs of age- 1 striped bass in each year. Alosa spp. became increasingly more important and Atlantic menhaden became less important to age-1 striped bass with the progression of each season. Marine and estuarine species, including
Anchoa spp. and Menidia spp., were important prey in age- 1 striped bass diets in 2002, while freshwater species, including yellow perch and shiners Notropis spp., occurred in age- 1 striped bass diets in 2003.

The prey community differed markedly between the two gear types and between years (Figure 5). Purse seine collections were dominated by clupeoid prey. Beach seine collections, in contrast, were more equitably composed of a mix of clupeoid prey and nonclupeoid prey, including Menidia spp., temperate basses Morone spp., sciaenids, and Notropis spp. Prey types measured for selectivity from the 2002 beach seine collections were Alosa spp., Atlantic menhaden, bay anchovy, Menidia spp., Morone spp., Mugil spp., sciaenids, and other fish (yellow perch, Fundulus spp., and $\mathrm{No}$ tropis spp.), which together made up $99.3 \%$ of potential fish prey from 247 collections. Alosa spp., Atlantic menhaden, bay anchovy, and sciaenids composed $99.1 \%$ of fish prey from the 64 purse seine collections in 2002. Alosa spp., Atlantic menhaden, Menidia spp., Notropis spp., white perch, yellow perch, and other fish (Fundulus spp., Mugil spp., ictalurids, and sciaenids) made up $95.6 \%$ of fish prey from the 198 beach seine col- 

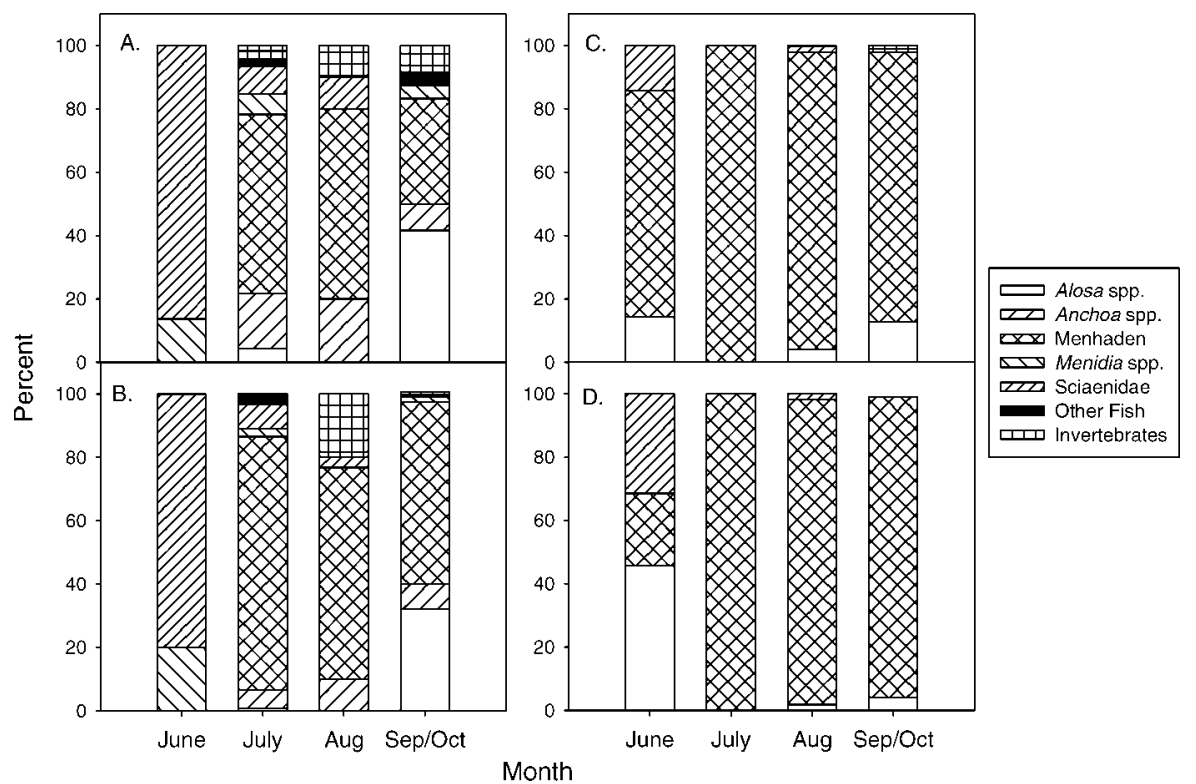

FIGURE 3.-Relative percent frequency by number (upper panels) and weight (lower panels) of major identifiable food groups consumed by age-2 striped bass collected in Albemarle Sound, North Carolina, in (A-B) 2002 and (C-D) 2003. The "other fish" category for 2002 includes Fundulus and Mugil spp.
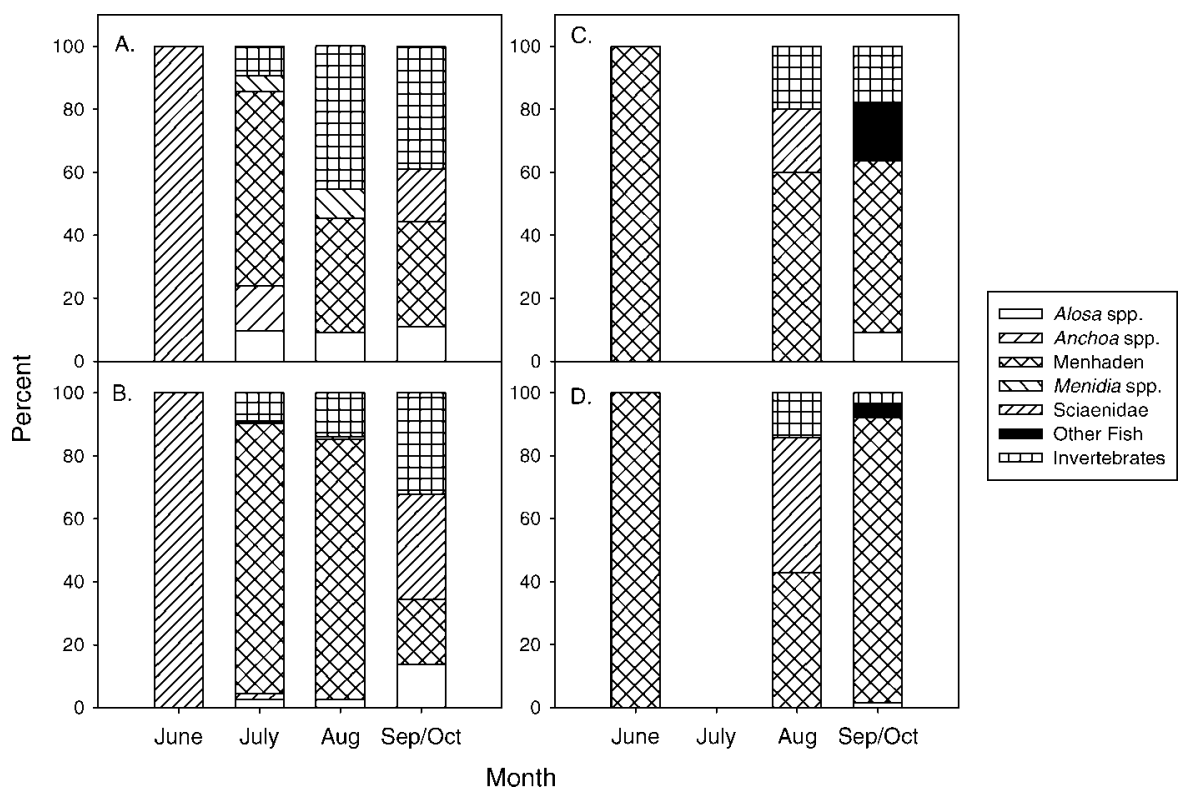

FIGURE 4.--Relative percent frequency by number (upper panels) and weight (lower panels) of major identifiable food groups consumed by age-3+ striped bass collected in Albemarle Sound, North Carolina, in (A-B) 2002 and (C-D) 2003. The "other fish" category for 2003 includes Lepomis spp. No identifiable foods were found in age$3+$ striped bass diets in July 2003. 

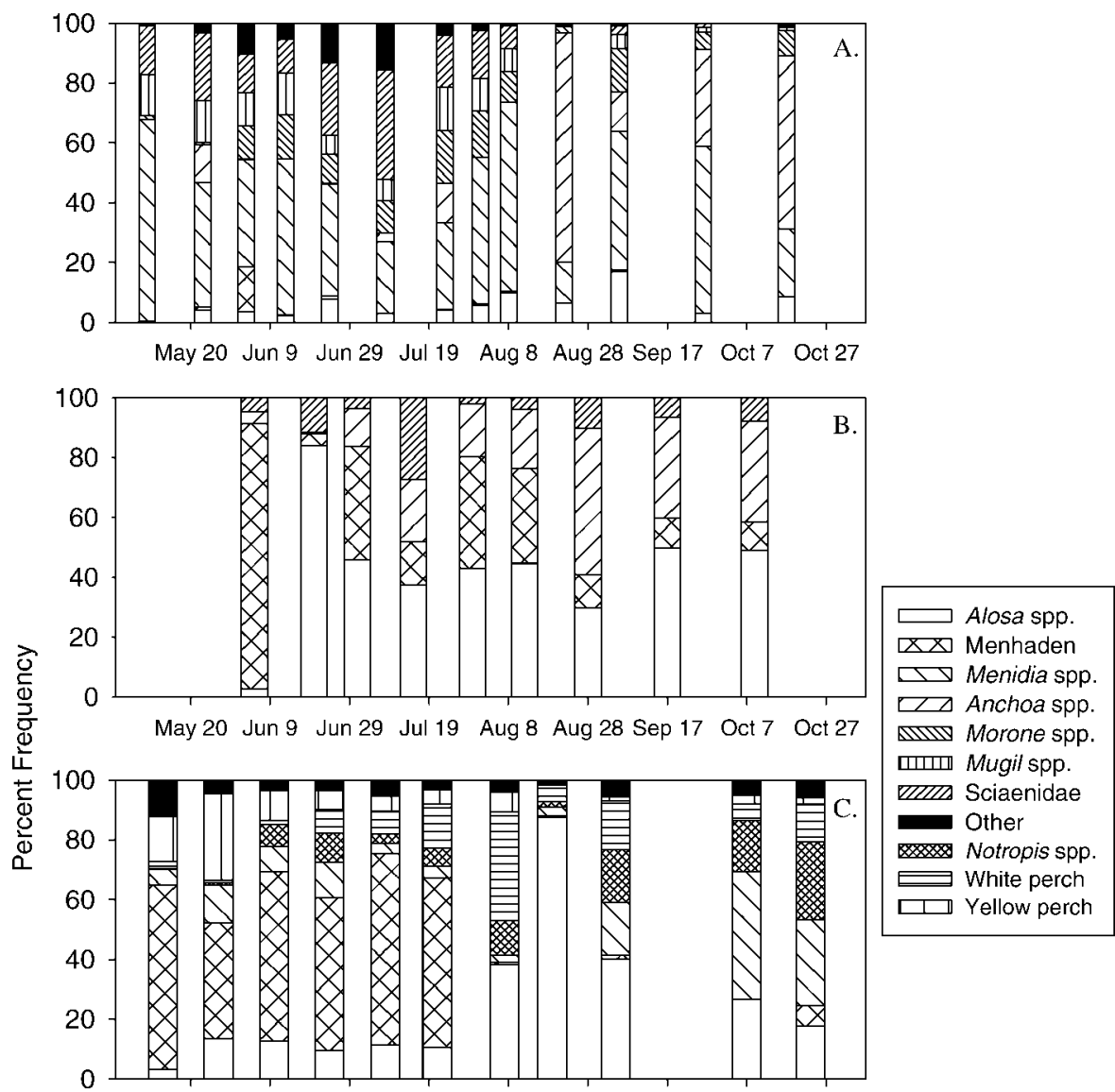

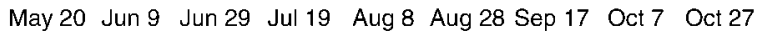

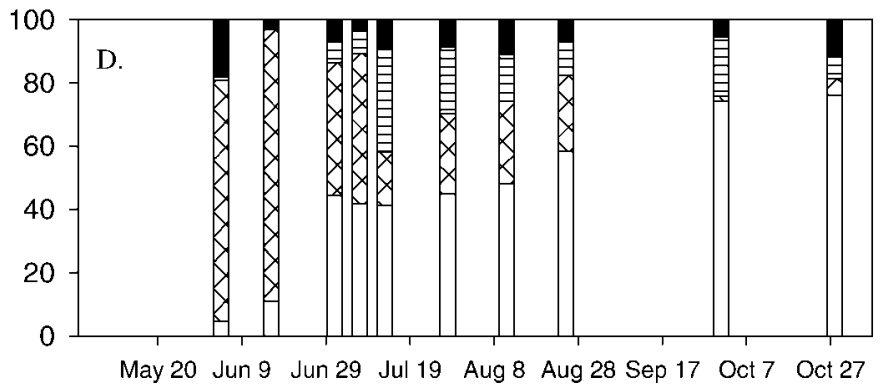

FIGURE 5.- Relative abundance (percent frequency) of striped bass prey groups collected in Albemarle Sound, North Carolina, by (A) beach seine in 2002, (B) purse seine in 2002, (C) beach seine in 2003, and (D) purse seine in 2003.

lections in 2003. Alosa spp., Atlantic menhaden, white perch, and other fish (ictalurids and sciaenids) composed $98.7 \%$ of fish prey from the 106 collections made by purse seining in 2003. We found that age- 0 alewives and American shad dominated the catch of alosines early in each year (May-July), while blueback herring dominated the catch of alosines later in the year (August-Octo- ber). Other dominant prey taxa in the environment in 2003 were yellow perch and Atlantic menhaden. Hurricane Isabel and associated debris permitted only one beach seine sampling trip (18 stations) in September 2003. No purse seine collections were performed during that month.

Age-1 striped bass selectivity varied similarly within each year; selectivity values for Atlantic 

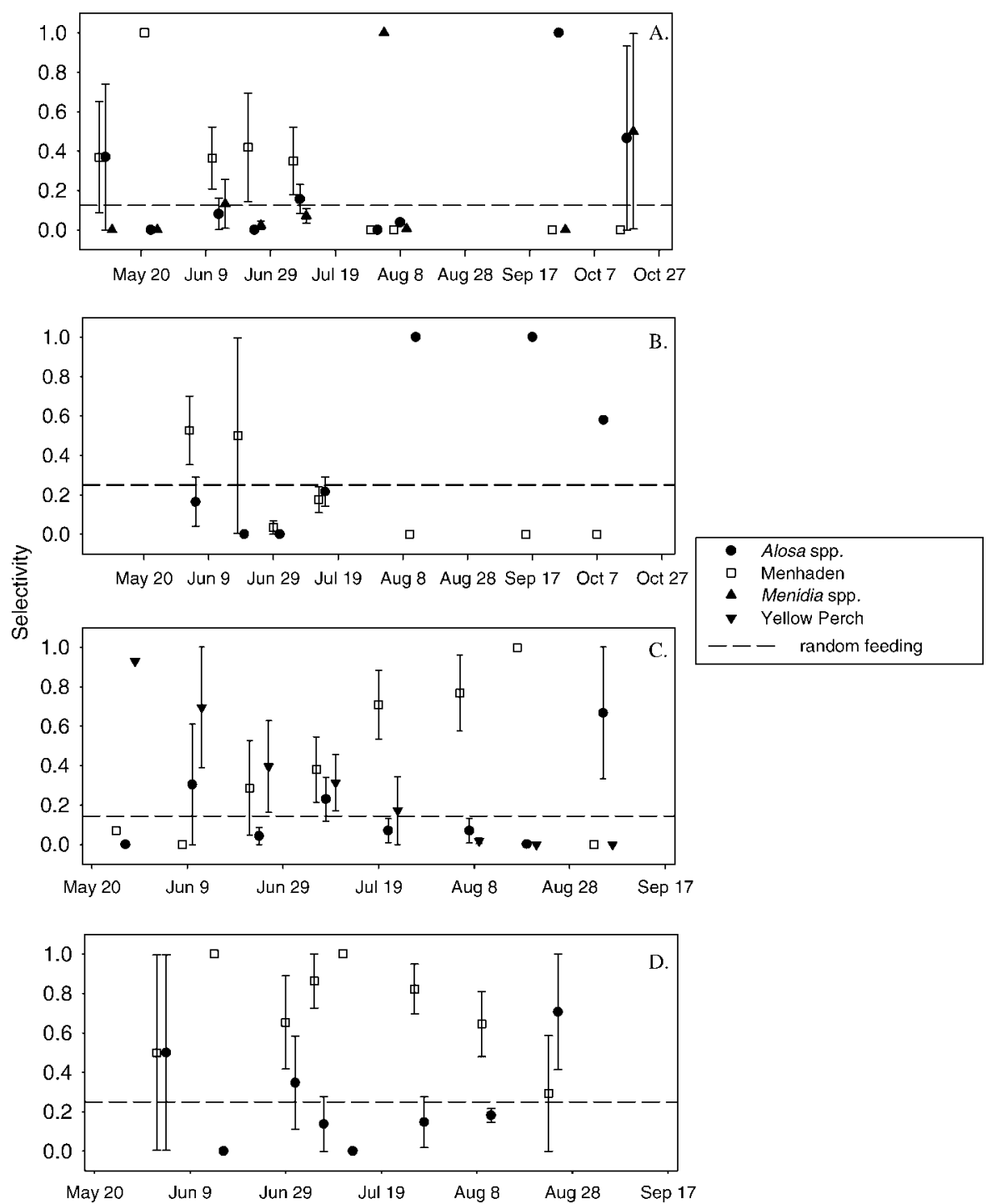

FIgURE 6.- Mean selectivity (Chesson's index $\alpha \pm \mathrm{SE}$ ) versus date for the dominant prey groups of age-1 striped bass collected in Albemarle Sound, North Carolina, by (A) beach seine in 2002, (B) purse seine in 2002, (C) beach seine in 2003, and (D) purse seine in 2003.

menhaden were higher in early summer than in late summer and early fall, whereas selection for Alosa spp. increased in late summer and early fall (Figure 6). Mean selectivity values for each year showed consistent selection by age- 1 striped bass for the suborder Clupeoidei (Alosa spp., Atlantic menhaden, and bay anchovy) and selection against spiny-rayed fishes (Table 2). Of the identifiable fish prey, soft-rayed fishes occurred in diets far more frequently than did spiny-rayed fishes ( $77.4 \%$ versus $22.6 \%$, respectively). Menidia spp., white perch, and yellow perch were the major taxa of spiny-rayed fishes found in diets. Age-2 and age- $3+$ striped bass selected for Atlantic menhaden and selected against Alosa spp. and spiny fishes (Table 2). Pearson's product-moment correlation coefficients between age- 1 striped bass selectivity and absolute abundance of dominant prey by gear type and year were nonsignificant $(P>0.05)$ except for the 2003 yellow perch beach seine data $(r=0.473 ; P=0.011)$.

For the majority of median tests, the median prey size from diets was either significantly smaller than or not significantly different from the me- 
TABLE 2.-Mean prey type selectivity (Chesson's index, $\alpha_{i}$; SD) for striped bass collected in 2002 and 2003 from Albemarle Sound, North Carolina, beach seines and purse seines. Values of $\alpha_{i}=1 / m$ represent random feeding, $\alpha_{i}>$ $1 / m$ represent selection for prey type $i$, and $\alpha_{i}<1 / m$ represent selection against prey type $i$, where $m$ is the number of prey types. Values significantly different $(P \leq 0.05)$ from $1 / m$ are indicated by plus signs for positive selection and minus signs for negative selection; $N$ is the number of independent groups.

\begin{tabular}{|c|c|c|c|c|c|}
\hline Year and gear & $1 / m$ & Prey type & Age 1 & Age 2 & Age $3+$ \\
\hline \multirow[t]{9}{*}{2002 beach seine $(N)$} & & & 27 & 15 & 12 \\
\hline & 0.125 & Alosa spp. & $0.171(0.313)$ & $0.064(0.247)$ & $0.087(0.288)$ \\
\hline & & Bay anchovy & $0.233(0.348)$ & $0.072(0.257)$ & $0 \quad(0.001)-$ \\
\hline & & Atlantic menhaden & $0.323(0.424)+$ & $0.730(0.456)+$ & $0.662(0.489)+$ \\
\hline & & Menidia spp. & $0.137(0.317)$ & $0 \quad(0)$ & $0.001(0.003)-$ \\
\hline & & Morone spp. & $0.033(0.134)-$ & $0 \quad(0)$ & $0 \quad(0)$ \\
\hline & & Mugil spp. & $0.003(0.011)-$ & $0.067(0.258)$ & $0 \quad(0)$ \\
\hline & & Sciaenidae & $0.001(0.002)-$ & $0.067(0.258)$ & $0.250(0.452)$ \\
\hline & & Other & $0.099(0.268)$ & $0 \quad(0)$ & $0 \quad(0)$ \\
\hline \multirow[t]{5}{*}{2002 purse seine $(N)$} & & & 22 & 15 & 12 \\
\hline & 0.25 & Alosa spp. & $0.246(0.352)$ & $0.058(0.158)-$ & $0.116(0.291)$ \\
\hline & & Bay anchovy & $0.395(0.384)$ & $0.241(0.358)$ & $0.030(0.105)-$ \\
\hline & & Atlantic menhaden & $0.295(0.402)$ & $0.601(0.420)+$ & $0.603(0.465)+$ \\
\hline & & Sciaenidae & $0.063(0.170)-$ & $0.101(0.265)-$ & $0.250(0.452)$ \\
\hline \multirow[t]{8}{*}{2003 beach seine $(N)$} & & & 28 & 25 & 5 \\
\hline & 0.143 & Alosa spp. & $0.182(0.308)$ & $0.042(0.200)-$ & $0.003(0.008)-$ \\
\hline & & Atlantic menhaden & $0.438(0.456)+$ & $0.916(0.276)+$ & $0.782(0.438)+$ \\
\hline & & Menidia spp. & $0 \quad(0)$ & $0 \quad(0)$ & $0 \quad(0)$ \\
\hline & & Notropis spp. & $0.065(0.208)$ & $(0)$ & $0.015(0.033)-$ \\
\hline & & White perch & $0.037(0.135)-$ & $(0)$ & $0 \quad(0)$ \\
\hline & & Yellow perch & $0.252(0.376)$ & $0 \quad(0)$ & $(0)$ \\
\hline & & Other & $0.027(0.103)-$ & $0.042(0.200)-$ & $(0.447)$ \\
\hline \multirow[t]{5}{*}{2003 purse seine $(N)$} & & & 25 & 26 & 5 \\
\hline & 0.25 & Alosa spp. & $0.259(0.358)$ & $0.059(0.197)-$ & $0.034(0.076)-$ \\
\hline & & Atlantic menhaden & $0.700(0.383)+$ & $0.888(0.274)+$ & $0.766(0.435)+$ \\
\hline & & White perch & $0.041(0.174)-$ & $0 \quad(0)$ & $0 \quad(0)$ \\
\hline & & Other & $0 \quad(0)$ & $0.053(0.206)-$ & $(0.447)$ \\
\hline
\end{tabular}

dian prey size sampled by beach or purse seining. Age-1 striped bass displayed consistently negative size selection for Menidia spp., mostly negative size selection for Alosa spp., neutral size selection for Atlantic menhaden, and a mix of neutral and positive size selection for yellow perch (Figure 7). Age-2 striped bass in 2002 displayed negative size selection for blueback herring and Atlantic menhaden and neutral size selection for bay anchovy (Figure 8). Numbers of prey lengths recovered from age- 2 striped bass in any month in 2003 and from age- $3+$ striped bass in any month of either year were not high enough to make similar comparisons.

The overall average prey-predator length ratio calculated for 2001-2003 gut data was 0.214. The average PPRs for dominant prey types were 0.276 for Atlantic menhaden, 0.242 for Alosa spp., 0.263 for Menidia spp., 0.230 for yellow perch, and 0.192 for Anchoa spp. The equation for the 50th quantile regression was prey $\mathrm{TL}=(0.13 \times$ striped bass $\mathrm{TL})+17.65$. The equation for the 5 th quantile regression was prey $\mathrm{TL}=(0.06 \times$ striped bass $\mathrm{TL})+14.66$. The equation for the 95 th quantile regression was prey $\mathrm{TL}=(0.23 \times$ striped bass
TL) + 24.27. The slopes of the 50th and 95th quantiles differed significantly from zero, while the slope of the 5th quantile did not. Larger striped bass continued to consume small prey while also including increasingly larger prey as predator size increased (Figure 9).

\section{Discussion}

Clupeoids dominated the diets of striped bass of all ages in terms of percent frequency and weight. Selection for clupeoids and against spiny-rayed fishes held not only across years but also for prey abundance data from two different gears (beach and purse seines) that were deployed in different habitats and that potentially had different efficiencies. Age-1 striped bass consumed clupeoid and nonclupeoid fishes, whereas age- $2+$ striped bass consumed only Atlantic menhaden on a consistent basis. Because striped bass of all ages displayed neutral or negative size selectivity of prey taxa, it was surprising that age- $2+$ striped bass selected against the relatively small Alosa spp. consistently in both years and that this taxon was relatively unimportant to older fish in terms of frequency and weight. 


\section{A. 2002 (continued)}
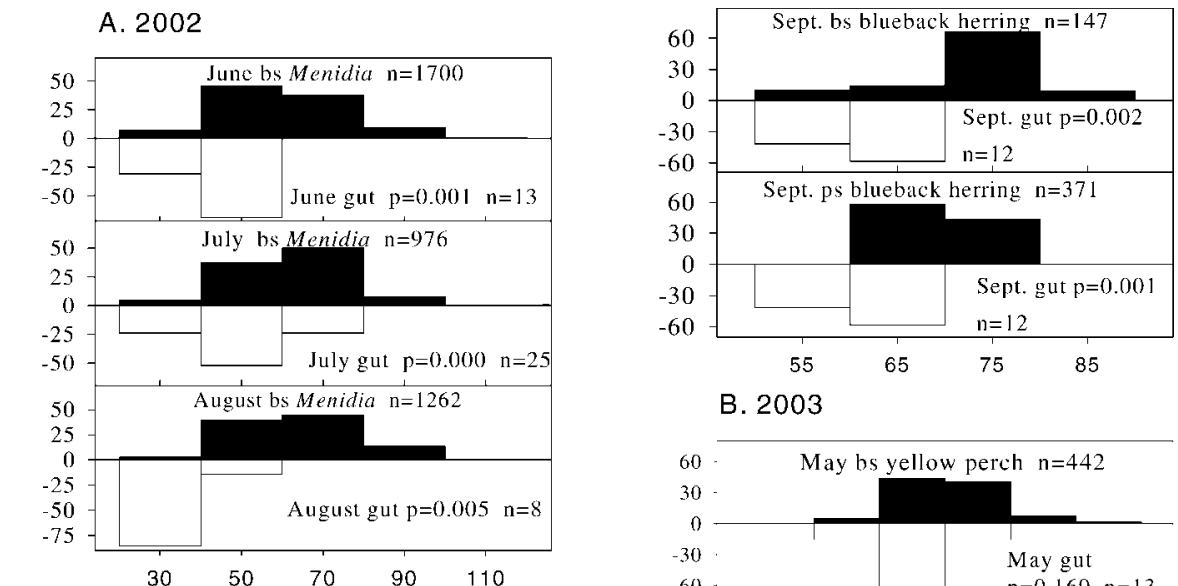

B. 2003
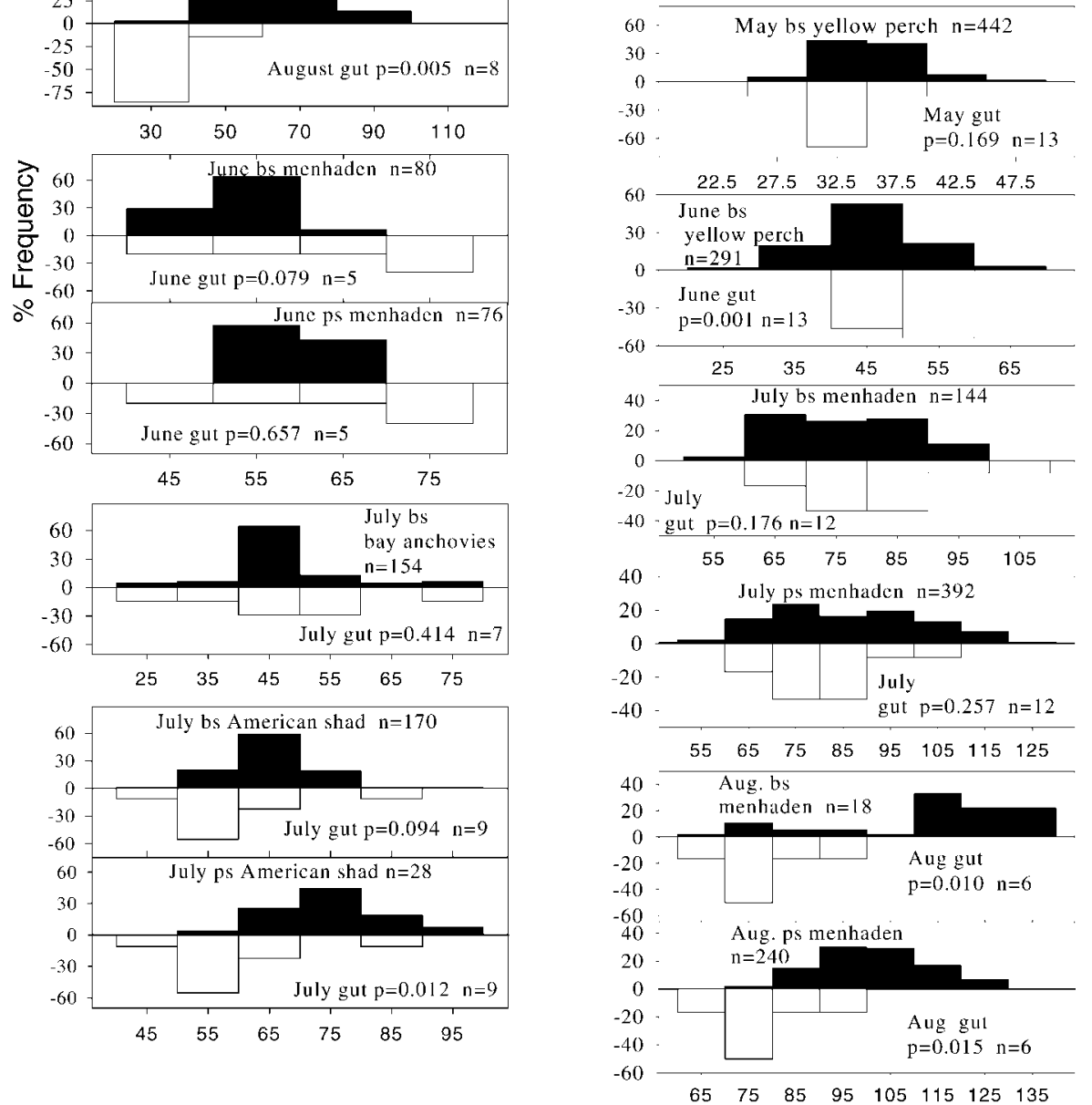

Total length $(\mathrm{mm})$

FIGURE 7.-Comparative percent length-frequency distributions of fish prey in the environment (positive $y$-axis) and diets (negative $y$-axis) of age-1 striped bass collected in Albemarle Sound, North Carolina, in 2002 and 2003. Each tick mark on the $x$-axis (prey length) represents the midpoint of that size-class (total length; mm). $P$-values are from chi-square test statistics computed from median tests (significance level $=0.05$ ). Sample sizes on each panel represent the number of prey measured from the environment and stomach contents. 


\section{A. Menhaden}

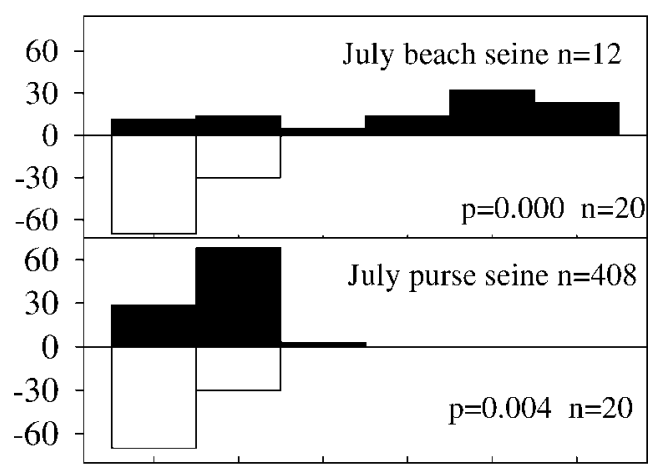

B. Bay anchovies

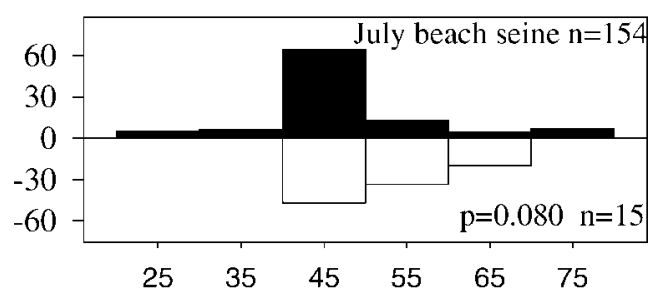

\section{Blueback herring}

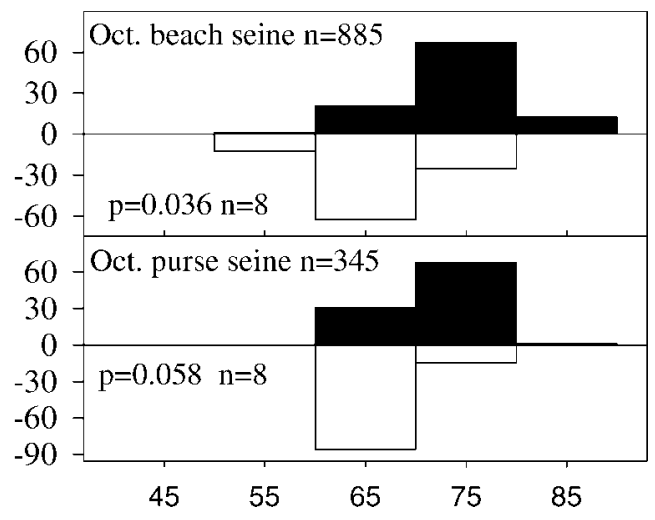

FIGURE 8.-Comparative percent length-frequency distributions of fish prey in the environment (positive $y$-axis) and diets (negative $y$-axis) of age- 2 striped bass collected in Albemarle Sound, North Carolina, in 2002. Each tick mark on the $x$-axis (prey length) represents the midpoint of that size-class (total length; $\mathrm{mm}$ ). $P$ values are from chi-square test statistics computed from median tests (significance level $=0.05$ ). Sample sizes on each panel represent the number of prey measured from the environment and stomach contents.
The importance of schooling pelagic fishes, particularly clupeoids, to the diets of older striped bass has also been documented for the Chesapeake Bay (Hartman and Brandt 1995a; Overton 2003; Walter and Austin 2003) and southern reservoirs (Matthews et al. 1988; Cyterski et al. 2002) and may be related to striped bass habitat preferences. Telemetered adult striped bass in Albemarle Sound have been found to select for deep water and against shallow water during the summer (Haeseker et al. 1996). The use of deep water by older striped bass would reduce their rate of encounter with prey that are more common in the littoral zone (Matthews et al. 1988).

Like Manooch (1973), we found that age-1 striped bass diets were dominated by fish throughout the May-October sampling period. The shift to piscivory probably occurs in winter or spring of the second year of life, as Cooper et al. (1998) found that age- 0 striped bass in Albemarle Sound consumed predominantly invertebrates in the fall. The onset of piscivory in age- 1 striped bass commences later in more northerly estuaries. For example, May-June diets of age-1 Chesapeake Bay striped bass were mostly comprised of invertebrates, and only in summer and fall did these fish begin consuming large percentages of Atlantic menhaden and bay anchovy (Hartman and Brandt 1995b). Buckel and McKown (2002) reported that invertebrates continued to be important components of the diet for age-1 striped bass in late summer and fall in New Jersey and New York embayments.

The difference in diet may be due to growth differences, as age-1 striped bass in Albemarle Sound tend to be larger than age-1 fish located farther north (e.g., Buckel and McKown 2002). This relatively large size and the availability of appropriately sized fish prey allows age- 1 striped bass to switch to piscivory early in the growing season and to maintain a size advantage over the abundant, newly recruited juvenile fish prey. Large size and fast growth of fish predators can limit the ability of fast-growing fish prey to exceed the sizes that are most vulnerable to predation (Rice et al. 1997).

We observed annual differences in the fish prey community and composition of striped bass diets that may have been related to water quality. Anchoa spp. were a common prey of age-1 striped bass in 2002, when monthly average salinity ranged from $2.0 \%$ to $7.6 \%$, but were largely nonexistent in prey collections and predator diets in 2003. In contrast, yellow perch were not identified 


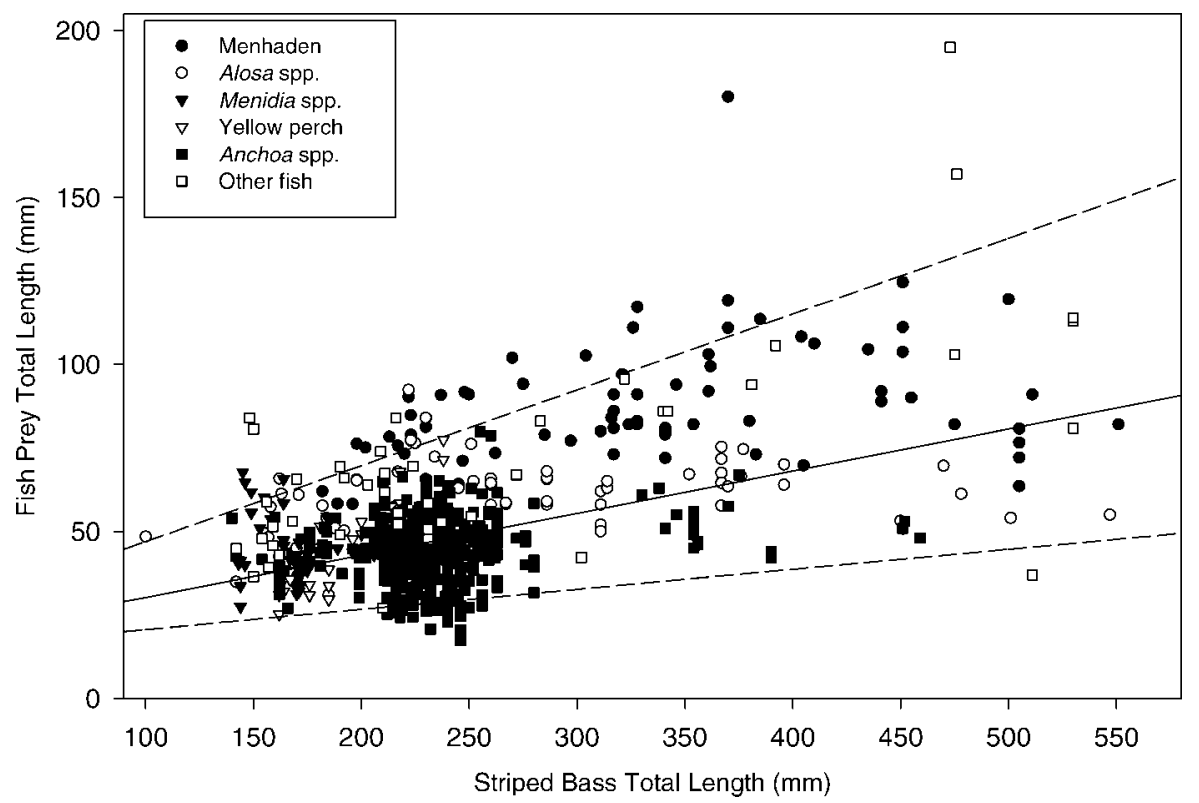

FIGURE 9.- Total length $(\mathrm{mm})$ of prey in stomach contents versus total length $(\mathrm{mm})$ of striped bass predators $(n$ $=815$ ) collected from Albemarle Sound, North Carolina, in 2001-2003. The "other fish" category includes striped bass, white perch, silver perch Bairdiella chrysoura, spot Leiostomus xanthurus, Atlantic croaker, Notropis spp., Fundulus spp., gobies Gobiosoma spp., and Lepomis spp. Upper and lower dashed lines represent the 95th and 5th regression quantiles, respectively. The solid line represents the 50th regression quantile.

in any age- 1 striped bass stomachs in 2002 but were a dominant prey in May and June of 2003, when salinity was less than $0.5 \%$. A similar diet change, related to spatial patterns in salinity, was reported by Manooch (1973). He found that Atlantic menhaden and blueback herring dominated striped bass diets in western Albemarle Sound, whereas Atlantic menhaden and bay anchovy dominated striped bass diets in the more saline eastern sound. Additionally, we observed bottom-water hypoxia in 2002 but not in 2003 . This could account for the higher 2002 beach seine catches of age-1 striped bass as well as the increased frequency of occurrence of littoral zone prey types (American shad and Menidia spp.) in 2002 diets.

Striped bass in Albemarle Sound did not feed randomly but showed selection for specific prey types. This selectivity was not generally related to prey abundance but did vary seasonally and annually. Temporal changes in selectivity were consistent with previous (qualitative) studies (ones that did not measure the prey field) showing that wild striped bass are opportunistic feeders (Gardiner and Hoff 1982; Cooper et al. 1998). In contrast, hatchery-reared striped bass in a freshwater impoundment fed almost exclusively on shads $D o$ rosoma spp. and failed to shift to alternate prey even when starving (Matthews et al. 1988). Chesson's index measures selection (active and/or passive) by a predator but cannot provide information on specific mechanisms responsible for selection for or against a prey taxon. Thus, it is difficult to speculate on the relative influence of each mechanism. Results suggest that factors in addition to relative prey abundance influence prey type selectivity and confound our ability to define predator responses to relative numbers of each prey. These factors likely include predator and prey habitat overlap (see above), PPR, prey anatomy, and prey behavior.

Prey species that grow rapidly should spend less time in those size-classes that are most vulnerable to predation (Post and Prankevicius 1987; Sogard 1997). In Albemarle Sound, age-0 Atlantic menhaden and yellow perch are similar in size to Alosa spp. early in the summer and are selected by age1 striped bass. As the season progresses, Atlantic menhaden and yellow perch achieve larger average sizes than the alosines, which begin to dominate age-1 striped bass diets. During the entire period from the onset of spring juvenile recruitment to fall emigration, the monthly average length for at least one species of Alosa was always less than or equal to $25 \%$ of the monthly average length of 
age-1 striped bass. The early recruiting, early emigrating alosines (alewives and American shad) are replaced by late-recruiting, late-emigrating blueback herring. The fact that the PPR of Atlantic menhaden was larger than that of Alosa spp. is one likely mechanism driving age- 1 striped bass selection against Atlantic menhaden in the fall (Chesson's index, $\alpha=0$ in September-October for both gear types and years).

Further proof that relative PPR influences striped bass diets comes from the testing of size selectivity. With the exception of the yellow perch data from June 2003 (when these prey were small relative to predators and other prey), we found that striped bass of all ages were either neutrally or negatively size selective for all prey types. Negative size selection in piscivores is most often attributed to passive processes (i.e., high capture success on relatively small prey) instead of active selection (Juanes 1994). Scharf et al. (2003) found significant negative relationships between capture success and PPR for age-1 striped bass and two prey taxa, bay anchovy and Menidia spp. Our prey and predator length data showed a trend of continued consumption of small fish prey with increasing striped bass size. This asymmetric pattern has been found in Chesapeake Bay striped bass by Overton (2003), who suggested that the asymmetry resulted from the relative abundance of small prey. Higher susceptibility to capture would also result in continued predation on small fish prey (Scharf et al. 2003).

Relative prey anatomy (spiny- versus soft-rayed fishes) was important in determining prey type selection by striped bass in Albemarle Sound. There was no significant positive selection for any spinyrayed prey taxa by any age-class of striped bass in any month of either year. We found no ictalurids, for example, in striped bass stomachs and rarely identified sciaenids or Mugil spp. in the diets of striped bass of any size. Spiny prey like ictalurids can be lethal to striped bass that attempt to ingest them (Scofield and Bryant 1926). Selection against spiny fishes holds across a range of fish predators in a variety of habitats (Knight et al. 1984; Webb 1986; Hoyle and Keast 1987). Ontogenetic changes in spination, from recently metamorphosed yellow perch with no rigid spines in early summer to older juveniles with rigid spines in mid- to late summer, may explain the temporal selectivity pattern for yellow perch in 2003.

Selection for Atlantic menhaden by striped bass was not expected given that Atlantic menhaden were larger than other available prey fishes. If At- lantic menhaden were relatively less vulnerable to our seines than were other prey, this could have caused a positive bias in selectivity estimates for Atlantic menhaden. We consider this explanation to be unlikely, however, because age-1 striped bass selectivity for Atlantic menhaden declined throughout the season even though Atlantic menhaden size (and, presumably, their ability to avoid the seine) was increasing. A second explanation for the selectivity for Atlantic menhaden by older striped bass is that smaller prey (e.g., alosines) are less profitable than prey of intermediate size (e.g., Atlantic menhaden) (Hartman 2000; Scharf et al. 2003). These profitability functions were determined from laboratory data and do not include encounter rate in their computations. A third factor that probably affected selectivity is prey behavior (Scharf et al. 2003). We speculate that prey behavior (high activity of Atlantic menhaden in open water) may have led to increased encounter rates or attack rates. Pelagic clupeids tend to form large schools, which may lead to higher predation rates than those experienced by nonschooling fishes or prey fishes that are more closely associated with the substrate (Beukers-Stewart and Jones 2004).

Striped bass have long been suspected of consuming large numbers of Atlantic menhaden in Atlantic coastal systems (Oviatt 1977), and modeling indicates that the current striped bass population size may be capable of limiting populations of clupeid prey along the U.S. Atlantic coast (Hartman 2003). The results of this study not only confirm the importance of these predator-prey relationships but also show how they vary seasonally and with changing environmental conditions. These complex patterns will need to be taken into account as ecosystem-based trophic models are developed to aid the management of important predator and prey fishes in Atlantic coast systems (Atlantic States Marine Fisheries Commission 2004).

\section{Acknowledgments}

We thank Sara Winslow, Jason Dilday, and Kathy Rawls of the NCDMF for their assistance throughout the project. We thank the Edenton National Fish Hatchery staff, who provided valuable logistic support. Josh Arnott, Aaron Bunch, Neal Morris, Andrew Gross, and Greg Cummings assisted in all phases of field sampling, stomach content analyses, and fish identification. Jim Morley, Nate Bacheler, Corey Oakley, and Dana Bethea helped with beach seine and purse seine collections. This study was funded by North Carolina Sea Grant project R/MRD-46. 


\section{References}

Atlantic States Marine Fisheries Commission. 2004. 2005 action plan. Atlantic States Marine Fisheries Commission, Washington, D.C.

Beukers-Stewart, B. D., and G. P. Jones. 2004. The influence of prey abundance on the feeding ecology of two piscivorous species of coral reef fish. Journal of Experimental Marine Biology and Ecology 299: 155-184.

Bowden, W. B., and J. E. Hobbie. 1977. Nutrients in Albemarle Sound, North Carolina. University of North Carolina, Sea Grant, Publication 75-25, Raleigh.

Boynton, W. R., T. T. Polgar, and H. H. Zion. 1981. Importance of juvenile striped bass food habits in the Potomac estuary. Transactions of the American Fisheries Society 100:56-63.

Buckel, J. A., D. O. Conover, N. D. Steinberg, and K. A. McKown. 1999. Impact of age-0 bluefish (Pomatomus saltatrix) predation on age- 0 fishes in the Hudson River estuary: evidence for density-dependent loss of juvenile striped bass (Morone saxatilis). Canadian Journal of Fisheries and Aquatic Sciences 56:275-287.

Buckel, J. A., and K. A. McKown. 2002. Competition between juvenile striped bass and bluefish: resource partitioning and growth rate. Marine Ecology Progress Series 234:191-204.

Carmichael, J. 1999. Status of blueback herring in the Chowan River, North Carolina, 1972-1998. North Carolina Department of Environment and Natural Resources, Morehead City.

Carmichael, J. 2003. Stock status of Albemarle SoundRoanoke River striped bass. North Carolina Division of Marine Fisheries, Morehead City.

Chesson, J. 1978. Measuring preference in selective predation. Ecology 59:211-215.

Chesson, J. 1983. The estimation and analysis of preference and its relationship to foraging models. Ecology 64:1297-1304.

Cooper, J. E., R. A. Rulifson, J. J. Isely, and S. E. Winslow. 1998. Food habits and growth of juvenile striped bass, Morone saxatilis, in Albemarle Sound, North Carolina. Estuaries 21:307-317.

Copeland, B. J., R. G. Hodson, S. R. Riggs, and E. C. Pendleton. 1984. The ecology of the Pamlico River, North Carolina: an estuarine profile. U.S. Fish and Wildlife Service Report FWS/OBS-82/06.

Cyterski, M., J. Ney, and M. Duval. 2002. Predator demand for clupeid prey in Smith Mountain Lake, Virginia. Fisheries Research 59:1-16.

Forney, J. L. 1974. Interactions between yellow perch abundance, walleye predation, and survival of alternate prey in Oneida Lake, New York. Transactions of the American Fisheries Society 103:15-24.

Gardiner, M., and T. Hoff. 1982. Diet of striped bass in the Hudson River estuary. New York Fish and Game Journal 29:152-165.

Garrett, R. G. 1993. Water quality from continuously monitored sites in the Albemarle Sound estuarine system, North Carolina, 1989-1991. U.S. Geolog- ical Survey, Open-File Report 93-69, Raleigh, North Carolina.

Giese, G. L., H. B. Wilder, and G. G. Parker, Jr. 1985. Hydrology of major estuaries and sounds in North Carolina. U.S. Geological Survey, Water Resources Investigation 79-46, Raleigh, North Carolina.

Haeseker, S. L., J. T. Carmichael, and J. E. Hightower. 1996. Summer distribution and condition of striped bass within Albemarle Sound, North Carolina. Transactions of the American Fisheries Society 125: 690-704.

Hartman, K. J. 2000. The influence of size on striped bass foraging. Marine Ecology Progress Series 194: $263-268$.

Hartman, K. J. 2003. Population-level consumption by Atlantic coastal striped bass and the influence of population recovery upon prey communities. Fisheries Management and Ecology 10:281-288.

Hartman, K. J., and S. B. Brandt. 1995a. Trophic resource portioning, diets, and growth of sympatric estuarine predators. Transactions of the American Fisheries Society 124:520-537.

Hartman, K. J., and S. B. Brandt. 1995b. Predatory demand and impact of striped bass, bluefish, and weakfish in the Chesapeake Bay: applications of bioenergetics models. Canadian Journal of Fisheries and Aquatic Sciences 52:1667-1687.

Hartman, K. J., and F. J. Margraf. 2003. U.S. Atlantic coast striped bass: issues with a recovered population. Fisheries Management and Ecology 10:309312.

Heath, R. C. 1983. Basic groundwater hydrology. U.S. Geological Survey, Water Supply Paper 2220, Raleigh, North Carolina.

Hoyle, J. A., and J. A. Keast. 1987. The effect of prey morphology and size on handling time in a piscivore, the largemouth bass (Micropterus salmoides). Canadian Journal of Zoology 65:1972-1977.

Juanes, F. 1994. What determines prey size selectivity in piscivorous fishes? Pages 79-100 in D. J. Stouder, K. L. Fresh, and R. J. Feller, editors. Theory and application in fish feeding ecology. University of South Carolina Press, Columbia.

Juanes, F., and D. O. Conover. 1994. Piscivory and prey size selection in young-of-the-year bluefish: predator preference or size-dependent capture success? Marine Ecology Progress Series 114:59-69.

Knight, R. L., F. J. Margraf, and R. F. Carline. 1984. Piscivory by walleyes and yellow perch in western Lake Erie. Transactions of the American Fisheries Society 113:677-693.

Livingston, P. A. 1985. An ecosystem model evaluation: the importance of fish food habits data. Marine Fisheries Review 47:9-12.

Manooch, C. S., III. 1973. Food habits of yearling and adult striped bass, Morone saxatilis (Walbaum), from Albemarle Sound, North Carolina. Chesapeake Science 14:73-86.

Matthews, W. J., L. G. Hill, D. R. Edds, J. J. Hoover, and T. G. Heger. 1988. Trophic ecology of striped bass, Morone saxatilis, in a freshwater reservoir 
(Lake Texoma, U.S.A). Journal of Fish Biology 33: 273-288.

Merriman, D. 1941. Studies on the striped bass (Roccus saxatilis) of the Atlantic coast. Fishery Bulletin 50: $1-77$.

Nielsen, L. A. 1980. Effect of walleye (Stizostedion vitreum vitreum) predation on juvenile mortality and recruitment of yellow perch (Perca flavescens) in Oneida Lake, New York. Canadian Journal of Fisheries and Aquatic Sciences 37:11-19.

Nelson, G. A., B. C. Chase, and J. Stockwell. 2003. Food habits of striped bass (Morone saxatilis) in coastal waters of Massachusetts. Northwest Atlantic Fisheries Science 32:1-25.

Overton, A. S. 2003. Striped bass predator-prey interactions in Chesapeake Bay and along the Atlantic coast. Doctoral dissertation. University of Maryland-Eastern Shore, Princess Anne.

Oviatt, C. A. 1977. Menhaden, sport fish, and fishermen. University of Rhode Island, Marine Technical Report 60 , Kingston.

Post, J. R., and A. B. Prankevicius. 1987. Size-selective mortality in young of-the-year yellow perch (Perca flavescens): evidence from otolith microstructure. Canadian Journal of Fisheries and Aquatic Sciences 44:1840-1847.

Raney, E. C. 1952. The life history of the striped bass, Roccus saxatilis (Walbaum). Bulletin of the Bingham Oceanographic Collection, Yale University 14: 5-97.

Rice, J. A., L. B. Crowder, and E. A. Marschall. 1997. Predation on juvenile fishes: dynamic interactions between size-structured predators and prey. Pages 333-356 in R. C. Chamber and E. A. Trippel, editors. Early life history and recruitment in fish populations. Chapman and Hall, London.

Scharf, F. S., F. Juanes, and M. Sutherland. 1998. Inferring ecological relationships from edges of scat- ter diagrams: comparison of regression techniques. Ecology 79:448-460.

Scharf, F. S., J. A. Buckel, P. A. McGinn, and F. Juanes. 2003. Vulnerability of marine forage fishes to piscivory: effects of prey behavior on susceptibility to attack and capture. Journal of Experimental Marine Biology and Ecology 294:41-59.

Scofield, N. B., and H. C. Bryant. 1926. The striped bass in California. California Fish and Game 12: 55-74.

Sogard, S. M. 1997. Size-selective mortality in the juvenile stage of teleost fishes: a review. Bulletin of Marine Science 60:1129-1157.

Sutton, T. M., M. J. Cyterski, J. J. Ney, and M. C. Duval. 2004. Determination of factors influencing stomach content retention by striped bass captured using gill nets. Journal of Fish Biology 64:903-910.

Tonn, W. M., C. A. Paszkowski, and I. J. Holopainen. 1992. Piscivory and recruitment: mechanisms structuring prey populations in small lakes. Ecology 73:951-958.

Tuomikoski, J. E. 2004. Effects of age-1 striped bass predation on juvenile fishes in western Albemarle Sound. Master's thesis. North Carolina State University, Raleigh.

Walter, J. F., III, and H. M. Austin. 2003. Diet composition of large striped bass (Morone saxatilis) in Chesapeake Bay. Fishery Bulletin 101:414-423.

Walter, J. F., III, A. S. Overton, K. H. Ferry, and M. H. Mather. 2003. Atlantic coast feeding habits of striped bass: a synthesis supporting a coastwide understanding of trophic biology. Fisheries Management and Ecology 10:349-360.

Webb, P. W. 1986. Effect of body form and response threshold on the vulnerability of four species of teleost prey attacked by largemouth bass (Micropterus salmoides). Canadian Journal of Fisheries and Aquatic Sciences 43:763-771.

Zar, J. H. 1996. Biostatistical analysis, 3rd edition. Prentice Hall, Englewood Cliffs, New Jersey. 